\title{
POTENSI KEARIFAN LOKAL TAMBI UMA SUKU ENDE SEBAGAI SUMBER BELAJAR BIOLOGI DAN PENDIDIKAN KARAKTER
}

\author{
Maria Waldetrudis Lidi $^{1 *}$, Maimunah H. Daud ${ }^{1}$, Morison Yosep M. Bolong ${ }^{1}$ \\ ${ }^{1}$ Universitas Flores, Jl. Sam Ratulangi, Ende, Nusa Tenggara Timur, Indonesia \\ * corresponding author | email : waldetrudismaria1024@gmail.com
}

Penelitian ini bertujuan untuk mengidentifikasi kearifan lokal suku Ende Tambi uma untuk dijadikan sebagai salah satu sumber belajar biologi dan pendidikan karakter yang kontekstual. Penelitian ini dilaksanakan di desa Gheoghoma, dan desa Watumbawu, Kabupaten Ende Propinsi NTT pada bulan Mei Tahun 2020. Jenis penelitian yang digunakan adalah deskriptif kualitatif. Teknik pengumpulan data berupa memadukan antara data observasi, wawancara dan studi literature yang ditindaklanjuti dengan tahap reduksi data, penyajian data, penyimpulan data. Hasil penelitian menunjukkan bahwa kearifan lokal Tambi uma berpotensi dijadikan sebagai sumber belajar biologi dan pendidikan karakter terutama mengandung nilai-nilai karakter luhur seperti gotong royong, persaudaraan, tanggung jawab, ketaatan, kesetaraan gender, nilai sosial, dan nilai komunikatif, yang berdampak pada sikap antusias peserta didik dalam mempelajari konsep.
\end{abstract}

\section{Kata Kunci : Tambi uma, Sumber belajar, Pendidikan karakter}

This study aims to identify local wisdom of the Ende Tambi uma tribe to serve as a source of contextual biology and character education. This research was conducted in Gheoghoma village and Watumbawu village, Ende Regency, NTT Province in May 2020. The type of research used is descriptive qualitative. The data collection technique is in the form of combining observation data, interviews and literature studies which are followed up with the stages of data reduction, data presentation, and data inference. The results showed that local wisdom of Tambi uma has the potential to be used as a source of learning biology and character education, especially containing noble character values such as mutual cooperation, brotherhood, responsibility, obedience, gender equality, social values, and communicative values, which have an impact on enthusiasm. learners in learning concepts.

\section{Keywords : Tambi uma, Learning resources, Character education}

Pemerintah melalui kementerian pendidikan dan kebudayaan menerapkan kurikulum 2013 dengan menitik beratkan pada aspek karakter dan pendekatan saintifik. Pembelajaran dengan pendekatan saintifik akan efektif jika peserta didik belajar sesuai dengan apa yang ada di lingkungannya. Hernani et al. (2012), menyatakan rendahnya pemahaman siswa akan konsep sains diakibatkan karena dalam praktik pembelajarannya konsep sains kurang dikaitkan dengan kehidupan sehari-hari. Lebih lanjut dikatakan bahwa hal ini perlu diatasi dengan mendasarkan pembelajaran 
sains pada situasi-situasi sosial yang kemudian dikembangkan dalam pembelajaran konseptual secara relevan. Faktanya, lingkungan sosial peserta didik sangat berkaitan dengan unsur kearifan lokal (local wisdom).

Kearifan lokal adalah nilai-nilai positif yang mengedepankan unsur-unsur keharmonisan dan keseimbangan antara kebutuhan masyarakat dan alam (Kusuma, 2018). Di sisi lain, Nadlir (2014), mengemukakan bahwa kearifan lokal adalah gagasan-gagasan, nilai, pandangan setempat yang bersifat bijaksana, penuh kearifan, bernilai baik, yang tertanam dan diikuti oleh anggota masyarakatnya. Hal ini berarti nilai-nilai positif yang terkandung dalam kearifan lokal sejalan dengan tujuan pendidikan nasional.

Nilai-nilai yang terkandung dalam kearifan lokal dapat diintegrasikan dalam pendidikan dengan mengedepankan prinsip-prinsip penyelenggaraan pendidikan yang diatur dalam Undang-Undang sistem pendidikan No. 20 Tahun 2003 pasal 36 ayat 3, dan Peraturan Menteri Pendidikan dan Kebudayaan No 22 Tahun 2016, yang menekankan pada keragaman potensi daerah dan lingkungan. Nadlir (2014), menyatakan penerapan pendidikan berbasis kearifan lokal baik dilaksanakan karena sesuai dengan kondisi lingkungan hidup, minat, kondisi psikis, dan kendala sosiologis dan kultural yang peserta didik hadapi.

Pada hakikatnya pembelajaran sains menekankan pada keterampilan proses dalam menemukan pengetahuan yang dikemas dalam kaidah-kaidah metode ilmiah. Guru hendaknya merancang kegiatan pengamatan terhadap fenomena yang terjadi disekitar peserta didik dan dikaitkan dengan pengalaman sosial, budaya, fisik dan psikologi. Pembelajaran sains berbasis kearifan lokal adalah pembelajaran yang berorientasi pada lingkungan kehidupan nyata yang juga meliputi nilai-nilai kehidupan yang berkembang dimasyarakat setempat. Hal ini berarti melalui kearifan lokal, pendidikan karakter dan peraihan konsep sains menjadi lebih bermakna karena berbasis kontekstual.

Kabupaten Ende memiliki beranekaragam warisan budaya yang tampak dalam keseharian hidup masyarakatnya. Salah satunya adalah yang terdapat pada suku ende yang merupakan penduduk asli di kabupaten Ende. Namun, pada kenyataannya pengintegrasian kearifan lokal dalam pembelajaran sains belum pernah diterapkan di lembaga pendidikan formal dan non formal. Minimnya penelitian terkait kearifan lokal masyarakat setempat yang berkaitan dengan pembelajaran, khususnya pembelajaran IPA merupakan salah satu kendala yang dihadapi dalam mengembangkan pendidikan yang berbasis kearifan lokal di Kabupaten Ende.

Kearifan lokal dapat diintegrasikan dalam pendidikan melalui sumber belajar. Sumber belajar adalah semua sumber yang mengandung pesan, disajikan melalui alat/bahan atau oleh dirinya sendiri yang dimanfaatkan untuk keberhasilan pembelajaran (Hafid (2016); Abdullah, (2012)). Penelitian terdahulu yang sejenis adalah oleh Lamahala, et al. (2018), memanfaatkan potensi lokal dan budaya masyarakat kupang di Nusa Tenggara Timur (NTT) dalam mengelola sumber daya alam Jagung (Zea mays L) sebagai sumber belajar IPA. Pengembangan bahan ajar tematik berbasis kearifan lokal Manggarai barat dan masyarakat Ngada NTT oleh Tinja et al. (2016) dan Laksana et al. (2016). Nuwa (2020), mengidentifikasi nilai-nilai karakter dari kearifan lokal Gong Waning di suku Sikka Krowe sebagai sumber pendidikan karakter. Beberapa penelitian tersebut hanya membahas secara terpisah tentang objek biologi sebagai potensi lokal dan nilai-nilai karakter dari kearifan lokal tetapi kurang menggali lebih dalam tentang karakteristik dari nilai-nilai kearifan lokal tersebut bahkan tidak mengkombinasikan antara pendekatan saintifik dan pendidikan karakter yang termuat di dalam kearifan lokal.

Salah satu kearifan lokal yang terdapat pada suku Ende adalah Tambi uma atau cangkul kebun. Tambi uma adalah bagian dari kegiatan berkebun yang diwariskan turun temurun. Sistem dalam tradisi Tambi uma menyerupai kegiatan arisan, dimana dilakukan secara bergiliran dan dapat menjadi layanan jasa bagi petani lainnya. Dalam kegiatan berkebun ini termuat objek-objek kajian biologi seperti makhluk hidup (objek material) dan proses yang berlangsung di dalam makhluk hidup tersebut (objek formal) dan juga terkandung nilai-nilai karakter yang berkembang dalam kebudayaan masyarakat lokal. Berdasarkan uraian di atas, penulis merasa perlu dilakukan kajian mendalam potensi Tambi uma dari sudut pandang pendidikan yang dapat dijadikan sebagai sumber belajar biologi dan 
sumber pendidikan karakter. Tujuan penelitian ini adalah mengidentifikasi potensi Tambi uma untuk dijadikan sebagai sumber belajar biologi dan pendidikan karakter yang kontekstual.

\section{METODE}

Jenis penelitian yang digunakan adalah deskriptif kualitatif dengan subjek penelitian kearifan lokal Tambi uma dimana penulis mengkaji dan mendeskripsikan tentang potensi kearifan lokal Tambi uma sebagai sumber belajar biologi dan pendidikan karakter. Penelitian dilaksanakan di kampung Mbomba Nua Puu, desa Gheoghoma, Kecamatan Ende Utara, dan Desa Watumbawu, Kelurahan Lokoboko Kecamatan Ndona Kabupaten Ende Propinsi NTT pada bulan Mei Tahun 2020. Nara sumber dalam penelitian adalah warga desa kampung Mbomba Nua Puu, dan Desa Watumbawu yang masih mewarisi dan melaksanakan tradisi ini.

Teknik yang digunakan dalam mengumpulkan data adalah memadukan antara data observasi, wawancara mendalam serta studi literatur. Data yang telah diperoleh selanjutnya dideskripsikan melalui tahap-tahap yaitu reduksi data, penyajian data, penyimpulan data. Potensi atau kelayakan Tambi uma sebagai sumber belajar dinilai berdasarkan kriteria berikut a) ekonomis, b) praktis, c) fleksibel, dan d) kesesuaian dengan tujuan pembelajaran. selanjutnya data yang dikumpulkan kemudian dianalisis dengan memberikan skor kelayakan sesuai Tabel 1.

Tabel 1.Skor Penilaian Kriteria Sumber Belajar

\begin{tabular}{|c|c|c|}
\hline Skor & Keterangan & Deskriptor \\
\hline \multirow[t]{4}{*}{4} & Sangat ekonomis & Jarak dari sekolah sangat dekat yaitu $0-2,5 \mathrm{~km}$ \\
\hline & Sangat Praktis & Sangat mudah dilaksanakan \\
\hline & Sangat Fleksibel & $>2$ kompetensi dasar yang sesuai \\
\hline & Sangat sesuai tujuan & $\begin{array}{l}\text { Komponen-komponen sumber belajar seluruhnya memiliki } \\
\text { kesesuaian dengan tujuan pembelajaran }\end{array}$ \\
\hline \multirow[t]{4}{*}{3} & Ekonomis & Jarak dari sekolah dekat yaitu 2,6-5,0 km \\
\hline & Praktis & Mudah dilaksanakan \\
\hline & Fleksibel & Terdiri dari 2 kompetensi dasar yang sesuai \\
\hline & Sesuai tujuan & $\begin{array}{l}\text { Sebagian besar komponen-komponen sumber belajar seluruhnya } \\
\text { memiliki kesesuaian dengan tujuan pembelajaran }\end{array}$ \\
\hline \multirow[t]{4}{*}{2} & Tidak ekonomis & Jarak dari sekolah jauh yaitu 5,1-7,5 km \\
\hline & Tidak praktis & Tidak mudah dilaksanakan \\
\hline & Tidak fleksibel & Hanya terdiri dari 1 kompetensi dasar \\
\hline & Tidak sesuai tujuan & $\begin{array}{l}\text { Sebagian kecil komponen-komponen sumber belajar seluruhnya } \\
\text { memiliki kesesuaian dengan tujuan pembelajaran }\end{array}$ \\
\hline \multirow[t]{4}{*}{1} & Sangat Tidak Ekonomis & Jarak dari sekolah sangat jauh yaitu $7.6-10.0 \mathrm{Km}$ \\
\hline & Sangat Tidak Praktis & Sangat sulit dilaksanakan \\
\hline & Sangat Tidak Fleksibel & Tidak sesuai dengan kompetensi dasar \\
\hline & Sangat tidak Sesuai tujuan & $\begin{array}{l}\text { Komponen-komponen sumber belajar tidak memiliki kesesuaian } \\
\text { dengan tujuan pembelajaran }\end{array}$ \\
\hline
\end{tabular}

Sumber: Sudjana (2012) dan Arikunto (2010).

Total nilai skor yang telah diperoleh selanjutnya dikonversi menjadi nilai mutu kelayakan Nilai yang telah diperoleh selanjutnya dikualitatifkan berdasarkan rubrik pada Tabel 2 untuk kemudian dideskripsikan.

Tabel 2. Skala Penilaian Kelayakan Sumber Belajar

\begin{tabular}{cc}
\hline Rentang & Keterangan Penilaian \\
\hline $3,1-4$ & Sangat Memenuhi Kriteria \\
$2,1-3$ & Memenuhi Kriteria \\
$1,1-2$ & Tidak Memenuhi Kriteria \\
$0-1$ & Sangat Tidak Memenuhi Kriteria \\
\hline
\end{tabular}

(Sumber: modifikasi Arikunto, 2010) 


\section{HASIL DAN PEMBAHASAN}

Tambi uma adalah salah satu kearifan lokal masyarakat suku Ende yang berada di Kabupaten Ende Propinsi Nusa Tenggara Timur. Arti Tambi uma dalam bahasa Indonesia adalah mencangkul kebun. Tambi uma telah dihidupi dan dilakukan oleh masyarakat setempat sebagai salah satu bentuk kegiatan gotong royong yang sarat akan nilai persaudaraan dan persatuan. Tradisi ini menjadi salah satu wadah bagi masyarakat untuk bekerja sama dalam bidang pertanian. Tambi uma dilaksanakan dalam rangka mempersiapkan lahan untuk menanam padi, jagung, umbi-umbian, sayuran atau pun kacang-kacangan. Tambi uma dilakukan secara kelompok baik dalam kelompok kecil maupun dalam kelompok besar. Kelompok Tambi uma bersifat heterogen dimana terdiri dari laki-laki dan perempuan. Kegiatan Tambi uma dilakukan dari pagi hari sampai sore hari namun uniknya memiliki jeda istirahat di siang hari. Sistem dalam tradisi Tambi uma menyerupai kegiatan arisan, dimana akan terjadi pergiliran pekerjaan untuk mencangkul kebun hingga semua anggota kelompok mendapatkan gilirannya. Tradisi Tambi uma ini juga menjadi tempat untuk menyediakan jasa bagi petani lain dalam mencangkul kebun.

Dalam tradisi Tambi uma terdapat aturan-aturan yang jelas walaupun sifatnya tersirat. Aturanaturan tersebut antara lain: 1) jika anggota berhalangan untuk hadir atau sakit, maka yang bersangkutan harus mencarikan pengganti untuk menggantikannya. Jika tidak ada pengganti maka akan dikenakan sanksi berupa membayar denda sesuai dengan kesepakatan bersama. Hal ini juga berlaku jika anggota hanya bekerja setengah hari saja. 2) setiap anggota wajib membawa makan siang atau makanan dapat juga disediakan oleh pemilik kebun, bergantung pada kesepakatan bersama. Jika kelompok Tambi uma mendapatkan panggilan atau menerima jasa untuk mencangkul kebun maka makanan akan disediakan oleh penyewa jasa tersebut.

Nilai-nilai karakter yang terkandung di dalam tambi uma dapat diintegrasikan ke dalam proses pembelajaran melalui keteladanan yang ditunjukkan oleh para petani dengan tujuan untuk mengenalkan, mengajarkan dan memantapkan karakter positif peserta didik sedangkan kegiatankegiatan di dalam tambi uma dapat dijadikan sebagai sumber belajar yang kontekstual bagi siswa. Penjabaran dari potensi tambi uma dalam pendidikan secara terperinci diuraikan sebagai berikut.

\section{Integrasi Tambi uma dalam pendidikan karakter}

Pendidikan karakter merupakan usaha menanamkan nilai-nilai karakter kepada peserta didik meliputi aspek pengetahuan, kesadaran, dan tindakan ( $a k s i o$ ) guna menjalankan nilai-nilai kebajikan baik bagi Tuhan, sesama dan juga untuk diri sendiri. Untuk membantu mengarahkan peserta didik dalam proses pembentukan kepribadian atau karakter, seorang tenaga pendidik dapat mengembangkannya lewat kearifan lokal. Nilai-nilai dalam kearifan lokal yang merupakan identitas peserta didik akan sangat membantu dalam proses pengintegrasian pendidikan karakter.

Tambi uma dapat diintegrasikan ke dalam pembelajaran karena mengandung nilai-nilai karakter luhur. Peserta didik dapat menemukan dan mempelajari nilai gotong royong, nilai persaudaraan, nilai tanggung jawab, nilai ketaatan, nilai sosial, nilai kesetaraan gender, serta nilai komunikatif. Nilai-nilai ini perlu diajarkan kepada peserta didik demi perkembangan kepribadiannya. Nilai-nilai ini tidak hanya bersifat teoritis namun nilai-nilai ini hidup dan berkembang dalam kebudayaan peserta didik dan menjadi ciri khas kebudayaannya dan daerahnya yang secara tidak langsung merupakan identitas dirinya sendiri. Hal ini diperkuat oleh Qodariah dan Armiyati (2013), yang mendefenisikan kearifan lokal sebagai gagasan-gagasan setempat yang bersifat bijaksana, penuh kearifan, bernilai baik, yang tertanam dan dikuti oleh anggota masyarakatnya.

Pemanfaatan kearifan lokal sebagai sumber pendidikan karakter telah banyak diteliti diantaranya adalah Hadi, et al. (2019), berdasarkan hasil temuannya menyimpulkan bahwa pembuatan terasi madura tidak hanya dapat dijadikan sebagai sumber belajar tetapi juga dapat menumbuhkan nilai kearifan lokal dan karakter siswa. Ramdani (2018), menyatakan bahwa Pembelajaran yang berbasis kearifan lokal tidak hanya menciptakan kemandirian bagi peserta didik untuk mengidentifikasi nilainilai karakter yang bersumber dari nilai-nilai hidup di keluarga dan di lingkungan masyarakatnya, tetapi juga menanamkan nilai-nilai karakter melalui pembiasaan yang sering dialami peserta didik 
dalam kesehariannya.

\section{Tambi uma sebagai sumber belajar biologi}

Kelayakan kearifan lokal tambi uma sebagai sumber belajar dianalisis mengikuti empat kriteria berikut 1) ekonomis, 2) praktis, 3) fleksibel dan 4) sesuai dengan tujuan. Hasil analisis kelayakan dirangkum dan disajikan dalam Tabel 3.

Tabel 3. Hasil Penilaian Kelayakan Tamb Uma Sebagai Sumber Belajar

\begin{tabular}{lccccccc}
\hline No & Nama & \multicolumn{4}{c}{ Hasil Penelitian } & Rata- & Kategori \\
& & Ekonomis & Praktis & Fleksibel & Sesuai Tujuan & \\
\hline 1 & Tambi uma & 3 & 3 & 4 & 4 & 3.5 & Sangat memenuhi kriteria \\
\hline
\end{tabular}

Tabel 3 menunjukkan bahwa tambi uma berpotensi atau layak dijadikan sebagai sumber belajar biologi karena berkategori sangat memenuhi kriteria dari aspek ekonomis, praktis, fleksibel dan sesuai tujuan. Untuk kategori pertama dinilai ekonomis. Hal ini sesuai dengan kenyataan yang ditemui di lapangan yakni 1) jarak antara sekolah-sekolah di kota Ende dengan lokasi kegiatan tambi uma berada pada kisaran jarak 2.6-5.0 Km bahkan ditemukan sebanyak sepuluh (10) sekolah berdampingan dengan lahan perkebunan warga; 2 ) sebagian besar masyarakat yang mendiami kota Ende bermata pencaharian sebagai petani dan memiliki lahan perkebunan disekitaran kota Ende. Tambi uma untuk kriteria kedua bernilai praktis karena mudah dilaksanakan. Kegiatan tambi uma (cangkul kebun) dapat ditemukan dalam keseharian masyarakat petani. Kriteria ketiga bernilai sangat fleksibel karena dapat disajikan sebagai sumber belajar biologi untuk delapan kompetensi dasar (KD). pada tingkat SMA/MA yakni pada (1) KD 3.2, KD 3.11, KD 4.14 kelas X materi ekosistem; (2) KD 3.5 kelas XI materi sistem gerak; dan (3) KD 3.9 kelas XI materi sistem ekskresi. Tingkat SD/MI pada KD 3.5 kelas V materi komponen ekosistem dan tingkat SMP/MTs pada KD 3.8 dan KD 4.12 kelas VII materi interaksi makhluk hidup. Kriteria keempat tambi uma berkategori sangat sesuai dengan tujuan karena komponenkomponen yang terdapat pada tambi uma sesuai dengan tujuan pembelajaran.

Tambi uma berpotensi sebagai sumber belajar biologi materi ekosistem karena dalam ekosistem kebun terdapat komponen-komponen ekosistem dan interaksi antara komponen-komponen ekosistem tersebut. Selain itu juga berpotensi sebagai sumber belajar materi sistem ekskresi dan sistem gerak pada tubuh manusia. Dalam aktivitas tambi uma terjadi proses ekskresi dalam bentuk keringat dan $\mathrm{CO}_{2}$ dan $\mathrm{H}_{2} \mathrm{O}$ lewat pernapasan. Selain itu aktifitas ini pun merangsang tubuh untuk membutuhkan asupan air yang banyak sehingga akan kembali terjadi proses ekskresi dalam urin. Kegiatan tambi uma juga melibatkan sistem gerak karena melibatkan tulang dan otot dalam aktivitasnya. Pemanfaatan tambi uma sebagai sumber belajar sesuai dengan defenisi sumber belajar oleh Kasrina et al. (2012), yakni sumber belajar adalah segala hal yang mendukung dan dapat dimanfaatkan dapat berupa manusia atau non manusia dan dapat juga yang dirancang atau yang dimanfaatkan.

Pemanfaatan tambi uma akan mempermudah peserta didik dalam memahami konsep ekosistem dan konsep terjadinya sistem ekskresi serta sistem gerak pada tubuh manusia. Hal ini disebabkan peserta didik belajar langsung dari pengalaman hidup kesehariannya sehingga meningkatkan antusias serta semangat peserta didik dalam mengikuti proses pembelajaran biologi. Hal ini akan memberikan efek positif dalam pemahaman akan konsep biologi.

Pemanfaatan kebun sebagai sumber belajar IPA berbasis kearifan lokal juga dikembangkan oleh Lamahala, et al (2018). Hasil temuannya membuktikan bahwa pemanfaatan potensi lokal berbasis kearifan lokal di Nusa Tenggara Timur yakni perkebunan jagung sebagai sumber belajar IPA di Sekolah dasar teruji dapat meningkatkan hasil belajar. Penelitian lainnya oleh Maharia et al. (2018), yang menyimpulkan bahwa kearifan lokal suku sungkai yakni bertangus, tarian daerah, tanaman obat, alat musik, kuwalu, jeghuk belimbing berpotensi sebagai sumber belajar IPA SMP. Didukung oleh temuan Muflihaini dan Suhartini (2019), yang menyatakan bahwa kearifan lokal Tarub berpotensi sebagai sumber belajar keanekaragaman hayati dan konservasi berbasis kearifan lokal budaya jawa. Menurut Qodariah dan Armiyati (2013), nilai -nilai dalam masyarakat sangat penting ditransformasikan dalam 
pendidikan karena pendidikan merupakan media pewarisan budaya. Disisi lain Putra (2017), menegaskan bahwa pembelajaran berbasis budaya lokal adalah pembelajaran kontekstual yang dirancang dengan mengintegrasikan budaya lokal dalam pembelajaran dengan tujuan sebagai bahan apersepsi, untuk memotivasi dan menerapkan pengetahuan.

Pada akhirnya dapat disimpulkan bahwa pemanfaatan kearifan lokal sebagai sumber belajar mengedepankan prinsip konstruktivisme. Konstruktivisme adalah filosofi dari pembelajaran kontekstual, yang mana peserta didik dibimbing untuk merekonstruksi pengetahuannya sendiri dan menjadikan pengetahuan tersebut menjadi bermakna untuk dirinya dan lingkungannya.

Hasil temuan peneliti dan beberapa temuan penelitian sebelumnya yang telah dijabarkan menunjukkan kepada kita bahwa sumber belajar biologi yang diambil dari kearifan lokal membantu tenaga pendidik dalam menanamkan nilai-nilai karakter karena melekat dengan keseharian peserta didik dan juga kearifan lokal adalah sumber belajar yang kontekstual. Selain itu, kearifan lokal merupakan suatu sumber inovasi yang perlu diperhatikan dan dikembangkan oleh semua tenaga pendidik, karena nilai-nilai yang terkandung dalam kearifan lokal merupakan jati diri peserta didik.

\section{KESIMPULAN DAN SARAN}

\section{Kesimpulan}

Berdasarkan uraian di atas dapat disimpulkan bahwa kearifan lokal suku Ende yakni tambi uma berpotensi digunakan sebagai sumber belajar biologi terkhususnya dalam pembelajaran materi ekosistem, sistem ekskresi dan sistem gerak pada tubuh manusia. Di sisi lain, dapat juga dimanfaatkan untuk pendidikan karakter karena mengandung nilai-nilai karakter luhur seperti gotong royong, persaudaraan, tanggung jawab, ketaatan, kesetaraan gender, nilai sosial, dan nilai komunikatif. Pengintegrasian kearifan lokal dalam pendidikan akan berdampak pada sikap antusias peserta didik dalam mempelajari materi pembelajaran karena sumber belajar yang digunakan sangat dekat dalam pengalaman kesehariannya. Dengan demikian pengintegrasian kearifan lokal dalam pendidikan dapat dijadikan sebagai salah satu solusi dalam menciptakan pembelajaran yang inovatif demi perkembangan pendidikan ke arah yang lebih baik.

\section{Saran}

Bagi para tenaga pendidik diharapkan dapat mengembangkan penelitian pendidikan yang berbasis kearifan lokal khususnya di wilayah Nusa Tenggara Timur.

\section{DAFTAR RUJUKAN}

Abdullah, R. 2012. Pembelajaran Berbasis Pemanfaatan Sumber Belajar. Jurnal ilmiah Didaktika. 12 (2): 216-231.

Arikunto, S. 2010. Prosedural Penelitian Suatu Pendekatan Praktek Edisi Revisi 2010. Rineka Cipta: Jakarta.

Hadi, P. W., Sari, F. P., Sugiarto, A., Mawaddah, W dan Arifin, S. 2019. Studi Etnosains Terasi Sebagai Sumber Belajar IPA Berbasis Kearifan Lokal. National Conference on Mathematics, Science, and Education (NACOMSE), 1(01), 343-348. Retrieved from http://proceeding.uim.ac.id/index.php/nacomse/article/view/182.

Hafid, H. A. 2016. Sumber dan Media Pembelajaran. Sulesana: Jurnal Wawasan Keislaman. 6 (2): 6978.

Hernani., A. Mudzakir dan H. Siti H. 2012. Meningkatkan Relevansi Pembelajaran Kimia Melalui Pembelajaran Berbasis Kearifan dan Keunggulan Lokal (Suatu Studi Etnopedagogi Melalui Indigenous Materials Chemistry). Jurnal Pengajaran MIPA. 17 (1): 96-106.

Kasrina., S. Irawati dan W. E. Jayanti. 2012. Ragam Jenis Mikroalga Di Air Rawa Kelurahan Bentiring Permai Kota Bengkulu Sebagai Alternatif Sumber Biologi SMA. Jurnal Exacta. 10 (1): 36-44.

Kusuma, R. S. 2018. Peran Sentral Kearifan Lokal Dalam Peningkatan Kualitas Pendidikan. Jurnal Pedagogic. 5 (2): 228-239.

Laksana, D.N.L., Kurniawan, P.A.W dan Niftalia, I. 2016. Pengembangan Bahan Ajar Tematik SD kelas 
IV Berbasis Kearifan Lokal Masyarakat Ngada. Jurnal Ilmiah Pendidikan Citra Bakti. 3 (1): 1-10. Lamahala, M.H., Lamen, S dan Uslan. 2018. Pengembangan Media Jaringan Epidermis Tanaman Jagung (Zea mays, L) Yang Tumbuh Di Kota Kupang Sebagai Sumber Belajar Tambahan Pembelajaran IPA SD Berbasis Kearifan Lokal. Jurnal IImiah Pendidikan Citra Bakti. 5 (2): 15-25. Maharia, A., Yolida, B dan Marpaung, R.R.T. 2018. Identifikasi Kearifan Lokal Suku Sungkai Sebagai Sumber Belajar IPA SMP. Jurnal bioterdidik: Wahana Ekspresi Ilmiah. 6 (4): 11-25.

Muflihaini, M.A dan Suhartini. 2019. Tarub Sebagai Sumber Belajar Biologi Keanekaragaman Hayati dan Konservasi Berbasis Kearifan Lokal Budaya Jawa. Prosiding symbion (symposium on biology education) Prodi Pendidikan Biologi, FKIP, Universitas Ahmad Dahlan , Vol 2, 282-288. Retrieved from seminar.uad.ac.id

Nadlir. 2014. Urgensi Pembelajaran Berbasis Kearifan Lokal. Jurnal Pendidikan Agama Islam. 2 (2): 299-330.

Nuwa, G. 2020. Nilai-Nilai Kearifan Lokal Gong Waning Pada Masyarakat Etnis Sikka Krowe Sebagai Sumber Pendidikan Karakter. Jurnal Edukasi dan Teknologi Pembelajaran. 1 (2): 48-53.

Putra, P. 2017. Pendekatan Etnopedagogi Dalam Pembelajaran IPA SD/MI. Primary Education Journal. 1 (1): 17-23.

Qodariah, L dan Armitayi, L. 2013. Nilai-Nilai Kearifan Lokal Masyarakat Adat Kampung Naga Sebagai Alternatif Sumber Belajar. Jurnal Socia. 10 (1): 10-20.

Ramdani, E. 2018. Model Pembelajaran Kontekstual Berbasis Kearifan Lokal Sebagai Penguatan Pendidikan Karakter. Jurnal Pendidikan IImu-IImu Social. 10 (1): 1-10.

Sudjana. 2012. Metodelogi Statistik. Tarsito: Bandung.

Tinja, Y., Thowaf, S.M., Hariyono. 2016. Pengembangan Bahan Ajar Tematik Berbasis Kearifan Lokal Manggarai Barat NTT. Seminar Nasional "pengembangan Profesionalisme Pendidik Untuk Membangun Karakter Anak" Vol 2. Retrieved from pasca.um.ac.id 